(C) The Author(s), 2021. Published by Cambridge University Press on behalf of the Arizona Board of Regents on behalf of the University of Arizona. This is an Open Access article, distributed under the terms of the Creative Commons Attribution licence (http://creativecommons.org/licenses/by/4.0/), which permits unrestricted re-use, distribution, and reproduction in any medium, provided the original work is properly cited.

\title{
WILLY WÖLFLI (1930-2014): A NUCLEAR PHYSICIST WITH PIONEERING VISIONS
}

\author{
Hans-Arno Synal ${ }^{1 *}$ • Jürg Beer $^{2} \cdot$ Martin Suter $^{1}$
}

${ }^{1}$ Laboratory of Ion Beam Physics, ETH Zurich, Otto-Stern-Weg 5, CH-8093 Zurich, Switzerland

${ }^{2}$ Swiss Federal Institute of Environmental Sciences and Technology (Eawag), CH-8600 Dübendorf, Switzerland

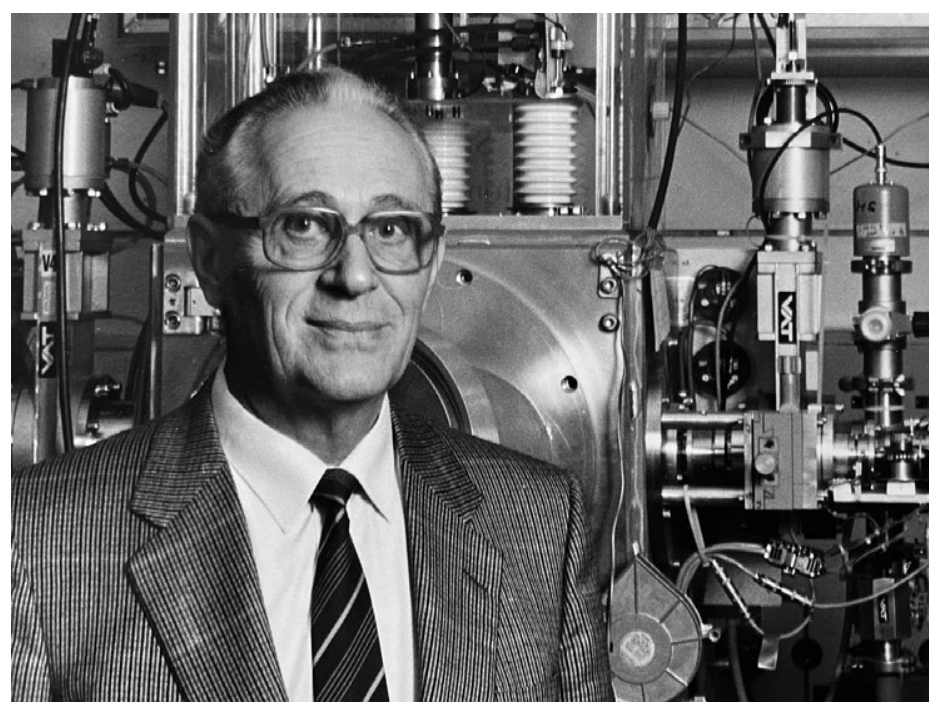

Willy Wölfli in front of the ion source of the Zurich AMS facility (1994).

Looking back on Willy Wölfli's scientific achievements is not an easy task. However, to fully understand his remarkable contributions to AMS, one has to begin with a look at his professional career. Influenced by the worldwide crises of the 1930s and 1940s, which also left their mark on Switzerland, Willy Wölfli first completed an apprenticeship as a highfrequency electrician before studying physics at the engineering school in Biel and later at the ETH Zurich. There, such famous people as Wolfgang Pauli and Paul Scherrer crossed his path. Driven by the enthusiasm of the time for the immense potential of nuclear power, he began his dissertation on the Saphir experimental nuclear reactor (Nuclear Power Switzerland). This research reactor was built at Argonne National Laboratory in 1955 as part of the Atoms for Peace Program initiated by Dwight D. Eisenhower (Eisenhower 1953) and was shown in operation at the Geneva Atomic Energy Exhibition (IAEA 1964) in autumn of the same year. Its research operations began two years later on the site of today's Paul Scherrer Institute in Würenlingen north of Zurich (Winkler and Buehrer 1987).

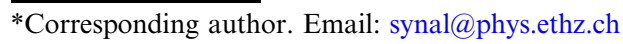


Despite attractive offers from the then flourishing nuclear industry, Willy Wölfli decided to pursue an academic career and began his research and teaching activities in 1967 at the Department of Mathematics and Physics at ETH Zurich. Around 1969, a new type of high-resolution X-ray detector based on semiconductors was developed and came on the market (Goulding et al. 1969). These detectors opened many new applications such as very sensitive methods for trace element studies with ion beams (Johansson et al. 1970). With great foresight, Willy Wölfli realized the potential of this new technique and started in 1972 a research program for high-energy proton induced X-ray spectroscopy (PIXE) in various fields of research such as archeology, geology, medicine, and environmental sciences. At the same time, he also began with more fundamental studies in heavy ion atom collisions such as the emission of continuous X-rays, which are caused by quasi molecular orbitals formed during ion-atom collisions (Wölfli et al. 1976).

During these experiments his group also discovered new rare X-ray lines so far unknown, which are produced by two electron transitions (Wölfli et al. 1975). A few years later the PIXE set-up was extended with a proton micro beam for mapping the trace element distribution in small areas (resolution about $10 \mu \mathrm{m}$ ) (Bonani et al. 1978). During this time period Willy Wölfli's group gained of lot of know-how on tandem accelerator technology such as ion optics, sputter ion sources, and charge changing processes in ion-atom collisions as well as on automated measurements with real time data analysis. Also, the preparation of small and ultra clean samples was essential in PIXE measurement. These skills became important later for the success of the AMS project. All these pioneering developments took place at the time when the first detection of ${ }^{14} \mathrm{C}$ with a tandem accelerator was achieved in Rochester and McMaster in 1977 (Bennett et al. 1977; Nelson et al. 1977). Hans Oeschger, who was running a conventional ${ }^{14} \mathrm{C}$ laboratory at the university of Berne immediately recognized the advantages of direct mass spectrometric detection of long-lived radionuclides in the 1960s (Oeschger et al. 1970), and travelled with his colleagues Bernhard Stauffer and Jürg Beer to the Laboratory for Nuclear Physics in Zurich to explore the possibility to convert the accelerator facility into an AMS spectrometer.

While the idea to launch such an applied project was not particularly well received by the hardcore nuclear physicists, Willy Wölfli was immediately enthusiastic and let himself be carried away by the remark: "If they have done it in the USA, we can also do it here." Thus, the Zurich-Berne axis was born and a joint application was eagerly submitted to the Swiss National Foundation with the goal to convert the Zurich EN tandem into a dedicated AMS spectrometer. It was clear to Willy Wölfli that such an ambitious project can only be successful if it is carried out by experienced people. With Georges Bonani, who had already proven his skills in setting up the proton microprobe, and Martin Suter, who was still a post-doc at the Oakridge National Laboratory at the time, he quickly formed a powerful team. In addition, benefitting from the excellent technical infrastructure of the ETH Zurich, he was able to create a leading AMS spectrometer in Zurich. Important design ideas were taken from the conceptual approaches of Kenneth Purser (Purser and Hanley 1978) and perfected in good Swiss style. The AMS system, which was ready for routine operation from 1982 onwards, soon distinguished itself by its exceptional precision often referred to as the "Swiss AMS clock."

This success attracted international attention and led to an increasing number of exciting collaborations with Wallace Broecker at Lamont-Doherty Geological Observatory, Ulrich Herpers and Rolf Michel at the University of Cologne, as well as with Karl-Otto Münnich 
and Augusto Mangini at the University of Heidelberg, and many others. Thanks to Henry Pollach and the international advisory committee, the 3rd AMS Conference (Wölfli et al. 1984) was held in Zurich in 1984. Among his many other achievements, Willy Wölfli's groundbreaking work showed that the Zurich AMS was already at that time able to measure ${ }^{14} \mathrm{C} /{ }^{12} \mathrm{C}$ isotope ratios with only 3 per mil uncertainty (Bonani et al. 1987). He became increasingly fascinated by the possibility to date very small samples with very high precision. He worked on the dating of the Shroud of Turin, the eruption of the volcano on Santorini, the parchment scrolls found at the Dead Sea, and on the Egyptian chronology.

At the age of 60, Willy Wölfli retired from his duties as head of the AMS laboratory. Health issues forced him to reduce his daily administrative work. This step was not easy for him, but knowing that his scientific life's work was in good hands and would be continued helped him to make this difficult decision. A successor was quickly found in Martin Suter, who successfully continued the Zurich AMS laboratory. Nevertheless, Willy Wölfli, who had decisively shaped the first ten years of AMS in Switzerland, remained true to research and his imaginative ideas continued to inspire all of us.

\section{REFERENCES}

Bennett CL, Beukens RP, Clover MR, Gove HE, Liebert RB, Litherland AE, Purser KH, Sondheim WE. 1977. Radiocarbon Dating Using Electrostatic Accelerators: Negative Ions Provide the Key. Science 198:508-510.

Bonani G, Beer J, Hofmann H, Synal HA, Suter M, Wölfli W, Pfleiderer C, Kromer B, Junghans C, Münnich KO. 1987. Fractionation, precision and accuracy in ${ }^{14} \mathrm{C}$ and ${ }^{13} \mathrm{C}$ measurements. Nuclear Instruments and Methods B 29(12):87-90.

Bonani G, Suter M, Jung H, Stoller C, Wölfli W. 1978. Digitally controlled scanning microprobe for protons and heavy ions. Nuclear Instruments and Methods 157:55-63.

Eisenhower DD. 1953. Speech to the General Assembly of the United Nations. December 8, 1953. Available at https://www. eisenhowerlibrary.gov/sites/default/files/file/ atoms_Binder13.pdf.

Goulding FS, Walton J, Malone DF. 1969. An optoelectronic feedback preamplifier for highresolution nuclear spectroscopy. Nuclear Instruments and Methods 71(3):273-279.

IAEA. 1964. The Geneva Conference-how it began. International Atomic Energy Agency Bulletin 6(3):S-1057-0008-03.

Johansson TB, Akselsson R, Johansson SAE. 1970. $\mathrm{X}$-ray analysis: elemental trace analysis at the

10-12 g level. Nuclear Instruments and Methods 84(1):141-143.

Nelson DE, Korteling RG, Stott WR. 1977. Carbon14: direct detection at natural concentrations. Science 198:507-508.

Nuclear Power Switzerland. Archive. PSI Würenlingen.

Oeschger H, Houtermans J, Loosli H, Wahlen M. 1970. Radiocarbon variations and absolute chronology. In: Olsen IU, editor. 12th Nobel Symposium. p. 471-496.

Purser K, Hanley PH. 1978. A carbon-14 dating system. Proceedings of the 1st AMS Conference. p. 165.

Winkler H, Buehrer W. 1987. Operation and utilization of the Swiss Research Reactor SAPHIR (IAEA-TECDOC-409). International Atomic Energy Agency (IAEA).

Wölfli W, Stoller C, Bonani G, Suter M, Stöckli M. 1975. Two-electron-one-photon transitions in heavy-ion collisions. Physical Review Letters 35(10):656-659.

Wölfli W, Stoller C, Bonani G, Stöckli M, Suter M, Dappen W. 1976. Periodic anisotropy fluctuations in Quasimolecular X-ray emission. Physical Review Letters 36(6):309-312.

Wölfli W, Polach HA, Andersen HH. 1984. Editorial. Nuclear Instruments and Methods B 5(2). ISSN 0168-583X. 